doi: 10.32620/oikit.2020.87.10

УДК 629.735.45.023:534.242

Є.Ю. Іленко, В.М. Онищенко

\title{
Динамічна реакція та стійкість пошкодженої конструкції транспортного літака
}

\author{
Харківський національний університет повітряних сил \\ імені Івана Кожедуба
}

\begin{abstract}
В процесі проектування і експлуатації ЛА актуальним $€$ визначення граничного стану конструкції з урахуванням динамічного навантаження конструкції і її стійкості. Граничний стан конструкції характеризується пошкодженнями, при яких конструкція ще зберігає можливість протистояти без катастрофрічного руйнування максимальним експлуатаційним навантаженням. Основним методом дослідження стійкості конструкції $\epsilon$ динамічний метод. Він дозволяє дослідити збурений рух конструкції як неконсервативної системи на деяке початкове збурення. Монотонний відхід системи від положення рівноваги або її коливання зі зростаючими амплітудами вказують на нестійкість конструкції. В роботі проаналізовано вплив пошкоджень конструкції літака на її динамічну стійкість на основі визначення динамічної реакції ЛА на деяке нестаціонарне збурення, наприклад, на дію турбулентної атмосфери. Використано метод розрахункового аналізу для дослідження динамічної стійкості конструкції. Основу цього методу становить математичне моделювання (ММ) функціонування ЛА в фрормі системи рівнянь руху і деформування конструкції. Розглянуто задачу динамічної аеропружності поведінка пружної пошкодженої конструкції ЛА в потоці повітря на початкове збурення. На основі моделювання на ЕОМ оцінюється динамічна стійкість пружної конструкції, її коливальний або квазістатичний (аперіодичний) деформаційний рух у межах льотного діапазону швидкостей ЛА. На основі параметричних досліджень оцінено межі нестійкості конструкції при заданих пошкодженнях для типових умов експлуатації. Відзначено актуальність напрямку, орієнтованого на створення і випереджальне функціонування ММ ЛА - їх математичних дублерів у процесі проектування i експлуатації ЛА в силу трудомісткості і обмежених можливостей наземних експериментальних установок і льотного експерименту. Відмічено, що умовою застосування цього методу є сформовані ММ функціонування ЛА і наявність інформації щодо масово-інерційних, жорсткісних і аеродинамічних характеристик ЛА.

Ключові слова: динамічна реакція; стійкість конструкції; атмосферна турбулентність; математична модель; частота та форма власних коливань; пружність конструкції; узагальнена сила; узагальнена маса.
\end{abstract}

Вступ. Основою безпеки ЛА $є$ забезпечення практичної відсутності неприпустимих пошкоджень конструкції, що призводять до тієї чи іншої катастрофрічної ситуації. Часткове або повне руйнування силових елементів відбувається через втомне або корозійне пошкодження, випадкове пошкодження в експлуатації або через виробничі дефекти. Крім того, існує проблема забезпечення бойової живучості ЛА після впливу засобів ураження (осколків, ударної хвилі та ін.).

Граничний стан конструкції характеризується пошкодженнями, при яких конструкція ще зберігає можливість протистояти без катастрофрічного руйнування максимальним експлуатаційним навантаженням. Актуальним $\epsilon$ визначення граничного стану конструкції та його меж 3 урахуванням динамічного навантаження і стійкості конструкції.

Постановка завдання дослідження. Основним методом дослідження стійкості конструкції є динамічний метод. Він дозволяє дослідити збурений рух 
конструкції як неконсервативної системи на деяке початкове збурення. Монотонний відхід системи від положення рівноваги або її коливання зі зростаючими амплітудами вказують на нестійкість конструкції.

В роботі поставлено за мету проаналізувати вплив пошкоджень конструкції літака на її динамічну стійкість на основі визначення динамічної реакції ЛА на деяке нестаціонарне збурення, наприклад, на дію турбулентної атмоссрери. Використано метод розрахункового аналізу для дослідження динамічної стійкості конструкції. Основу цього методу становить ММ функціонування ЛА в формі системи рівнянь руху і дефрормування конструкції [1, 2]. Розглянуто задачу динамічної аеропружності - поведінку пружної пошкодженої конструкції ЛА в потоці повітря на початкове збурення. На основі моделювання на ЕОМ оцінюють динамічну стійкість пружної конструкції, ії коливальний або квазістатичний (аперіодичний) деформаційний рух у межах льотного діапазону швидкостей ЛА. На основі параметричних досліджень оцінюють межі нестійкості конструкції при заданих пошкодженнях для типових умов експлуатації.

При побудові ММ аеропружності ЛА використовують метод заданих форм. Деформацію планера представляють шляхом розкладання ії за власними функціями. Частоти і форми власних коливань конструкції отримують методом дискредитації [3]. Розглядають сумісні згинально-крутильні коливання ЛА. Згідно з методом заданих фрорм, переміщення та кути закручування перерізу несучої поверхні описують у вигляді добутку фрорм на узагальнені координати $q(t)$, що залежать тільки від часу:

$$
y(z, t)=\sum_{i=1}^{N} f_{i}(z) q_{i}(t) ; \quad \vartheta(z, t)=\sum_{i=1}^{N} \varphi_{i}(z) q_{i}(t),
$$

де $N$ - число тонів власних коливань, що утримуються. При вільних коливаннях невідомими $€ 2 n+1$ величин: $n$ переміщень осі жорсткості в заданих точках несучої поверхні $f_{1}, f_{2}, \ldots, f_{n}, n$ кутів повороту перерізів навколо осі жорсткості в цих точках $\varphi_{1}, \varphi_{2}, \ldots, \varphi_{n}$ і частота $\omega$ власних коливань.

Вводять вектор-стовпець узагальнених переміщень

$$
A^{T}=\left(f_{1}, f_{2}, \ldots, f_{n}, \varphi_{1}, \varphi_{2}, \ldots, \varphi_{n}\right) \text {. }
$$

Задача визначення форм і частот власних коливань може бути зведена до задачі на власні значення матричного рівняння

$$
-A=\delta M \ddot{A},
$$

де $\delta$ і $\mathrm{M}$ - матриці коефіцієнтів піддатливості і мас системи. Введемо матрицю

$$
B=\delta M,
$$

тоді справедливе рівняння

$$
-A=B \ddot{A} .
$$

Для вектора-стовпця амплітуд узагальнених переміщень маємо

$$
\ddot{A}=-\omega^{2} \sin (\omega t+\alpha) A,
$$

отже,

$$
B\{A\}=\frac{1}{\omega^{2}}\{A\}
$$


Власні частоти пов'язані 3 власними значеннями матриці $B$ співвідношенням

$$
\frac{1}{\omega^{2}}=\lambda
$$

тоді $2 n$ частот визначають так:

$$
\sqrt{\frac{1}{\lambda}}=\omega
$$

Розглянуто випадок поздовжнього збуреного руху ЛА внаслідок впливу на ЛА дискретного пориву типу «одиниця мінус косинус», регламентованого в НЛГ [1]. Аеродинамічні характеристики ЛА визначаються методами нестаціонарної аеродинаміки на основі гіпотези квазістаціонарності [1].

Збурений рух ЛА як твердого тіла лінеаризований щодо базового режиму прямолінійного горизонтального польоту. Рівняння пружного деформування та коливань конструкції записані на основі розкладання руху за власними функціями [2]:

$$
\begin{aligned}
& M U_{0}\left(\Omega_{z}-\dot{\alpha}\right)=Y, \\
& I_{z} \Omega_{z}=M_{z}, \\
& M_{l}\left(\ddot{q}_{l}+2 \kappa_{l} \omega_{l} \dot{q}_{l}+\omega_{l}^{2} q_{l}\right)=Q_{l},
\end{aligned}
$$

де $M$-- маса ЛА; $\Omega_{z}$-- проекція вектора абсолютної кутової швидкості відносно осі $O z ; \alpha$-- кут атаки ЛА; $Y$-- проекція поверхневої сили на вісь у зв'язаної системи координат; $I_{z}$-- момент інерції ЛА відносно осі $O z ; M_{z}$-- момент тангажа відносно осі $O z ; l=1,2 \ldots N, N$ - число утримуваних фрорм власних коливань; $M_{l}$-- узагальнена маса; $q_{l}$-- невідомі узагальнені координати; $\kappa_{l}$-коефіцієнти конструкційного демпфрірування; $\omega_{l}$-- частоти власних коливань; $Q_{l}$-- узагальнені сили, які розраховують для зв'язаної задачі аеропружності.

Реалізація поставленого завдання. Результати числових розрахунків динамічної стійкості конструкції наведена для транспортного літака масою $m=38000$ кг, який здійснює горизонтальний політ зі швидкістю $V=820$ км/год. У момент часу $t=0$ діє висхідний порив інтенсивності $W=10 \mathrm{M} / \mathrm{c}$, який миттєво охоплює весь літак. Внаслідок цього відбувається збурений просторовий рух літака, а в конструкції збуджуються пружні коливання. Порівнюється динамічна реакція вихідної конструкції і пошкодженої, в якій зменшена згинальна і крутильна жорсткості крила.

Динамічні характеристики пружної конструкції визначають для ії дискретної розрахункової моделі, яка має 72 степеня вільності. Частоти перших трьох сумісних згинально-крутильних коливань консолі крила для вихідної конструкції становлять $f_{i}=2,39 ; 5,03 ; 10,77(i=1 . . .3)$ Гц, а для пошкодженої після зменшення згинальної та крутильної жорсткості $f_{i}=1,62 ; 2,35 ; 6,56(i=1 . . .3)$ Гц. Видно, що частоти пошкодженої конструкції суттєво зменшилися.

На рис. 1 показані перші дві фрорми власних коливань консолі крила, які відбуваються з частотами 1,62 та 2,35 Гц. Для наочності на рис. 1,в і г показана 
фрорма осі жорсткості від згинання, а на рис. 1,д і е зображене закручування осі жорсткості. Як видно, перша фрорма характеризується в основному згинальними деформаціями, а друга - як згинальними, так і крутильними.

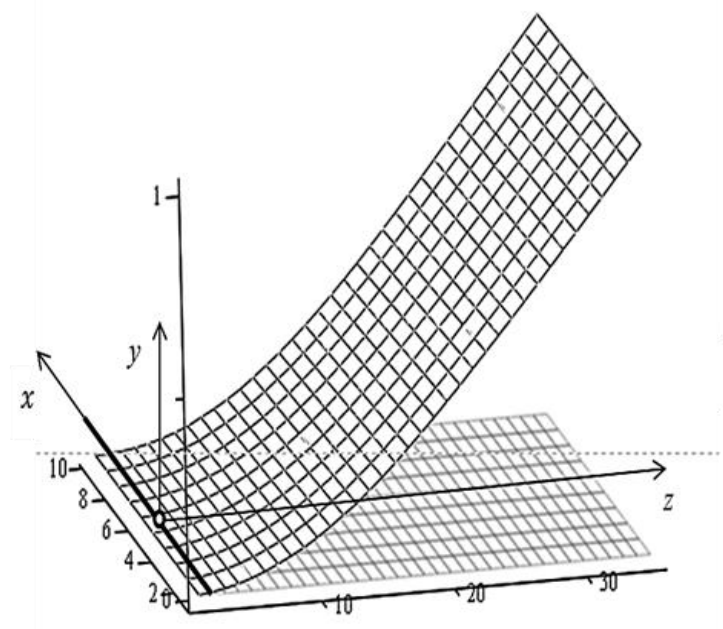

a

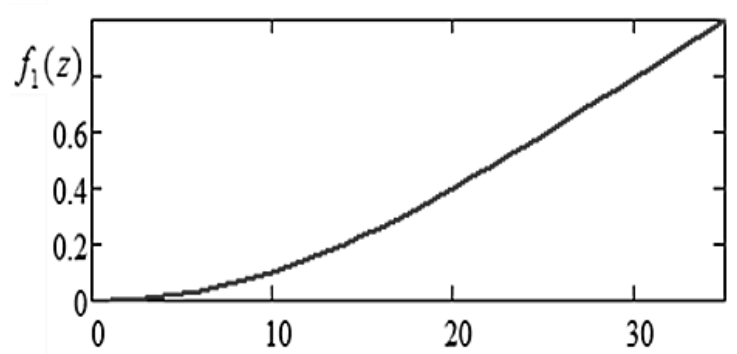

B

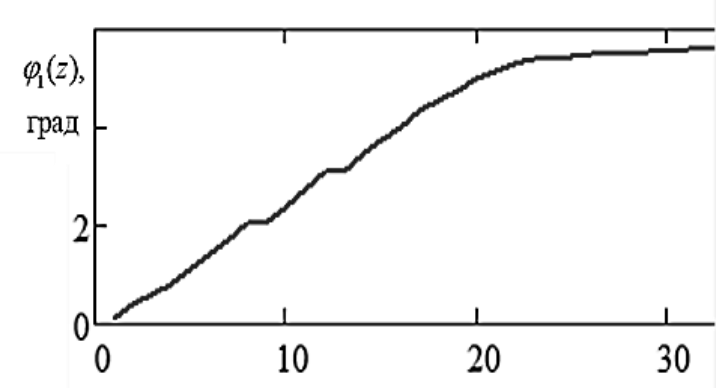

Д

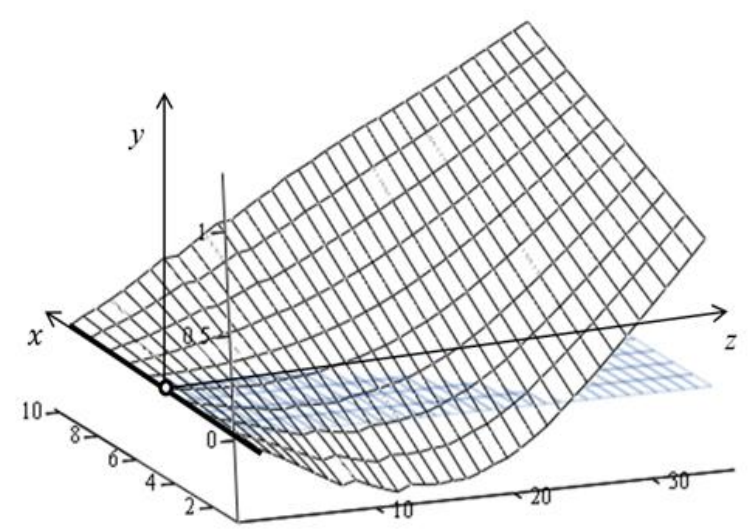

6

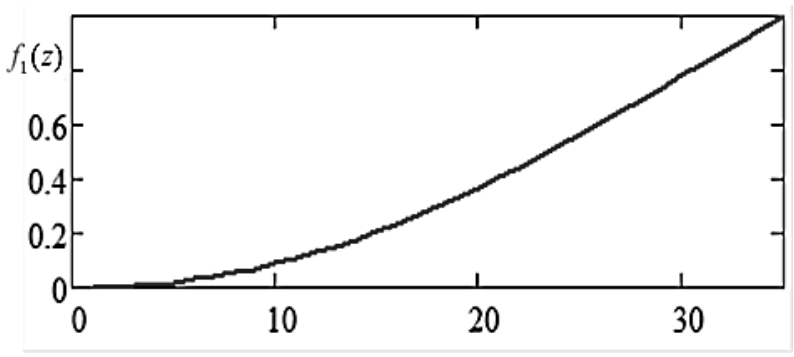

$\Gamma$

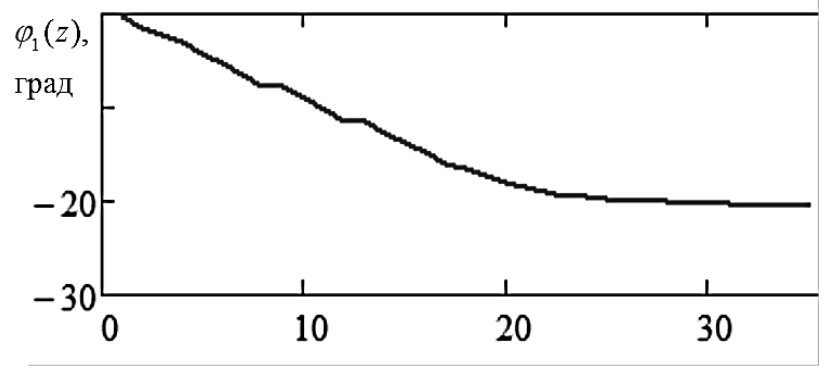

e

Рис. 1. Перша та друга форми згинально-крутильних коливань

У рівняннях (10) враховані внутрішні сили тертя, що діють в конструкції. Коефіцієнт конструкційного демпфірування для всіх форм становить $\kappa_{l}=0,03(l=1 \ldots 4)$. В розрахункову схему введені також аеродинамічні сили демпфірування, які пов'язані із згинальними коливаннями. Достатньо великі лінійні швидкості несучих поверхонь при коливаннях враховують при обчисленні аеродинамічного навантаження. 
В непошкодженій конструкції від висхідного пориву виникає збурений короткоперіодичний рух. Кут атаки $\alpha$ змінюється в межах від - 1,3 до 0,7 град, а кут нахилу траєкторії - від - 0,3 до 0,5 град. За декілька секунд коливання ЛА майже припиняються. В конструкції збурюються пружні коливання. На рис. 2 показано зміну першої узагальненої координати. Виникає в основному деформації згинання крила, кручення невелике. Максимальне переміщення кінця крила від згинання становить приблизно 0,2 м. Після закінчення дії пориву коливання крила з часом загасають. Тому конструкція $є$ стійкою.

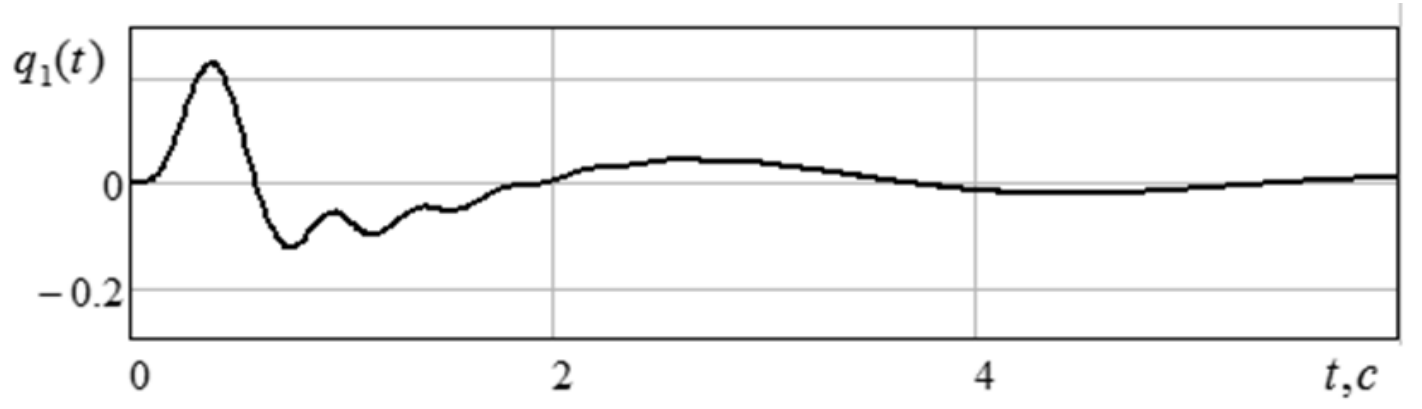

Рис. 2. Зміна першої узагальненої координати вихідної конструкції

Пошкодження в розрахунках підібрані такими, щоб конструкція стала нестійкою. На рис. 3, 4 і 5 показано зміну трьох узагальнених координат пошкодженої конструкції.

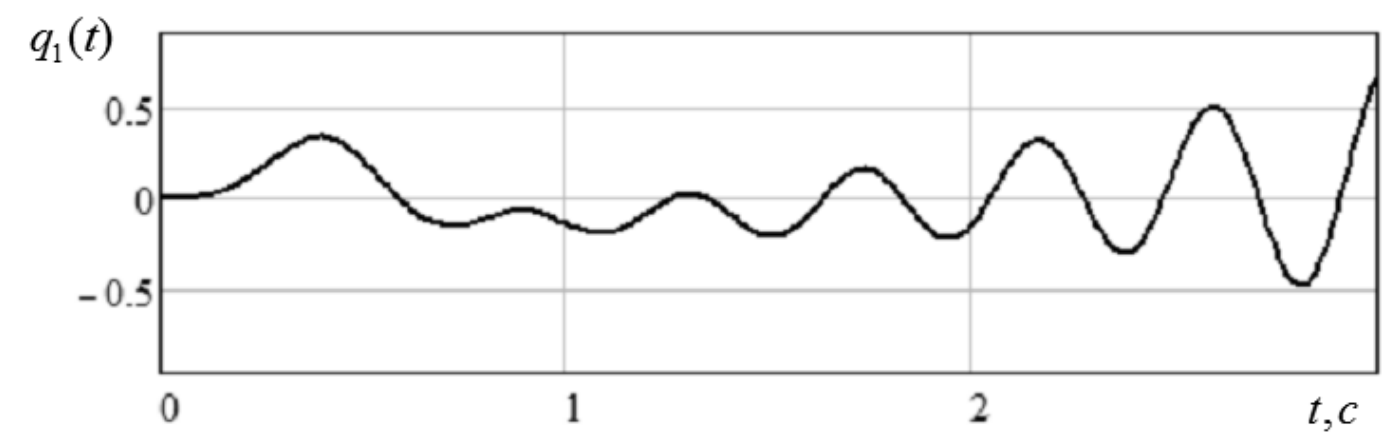

Рис. 3. Зміна першої узагальненої координати пошкодженої конструкції

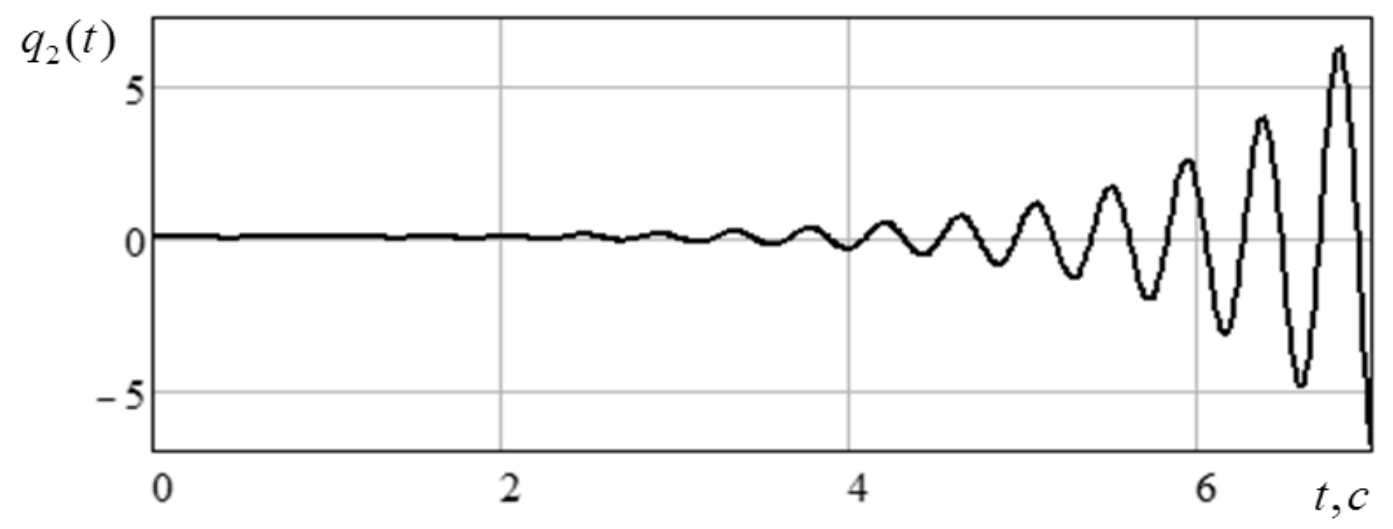

Рис. 4. Зміна другої узагальненої координати пошкодженої конструкції 


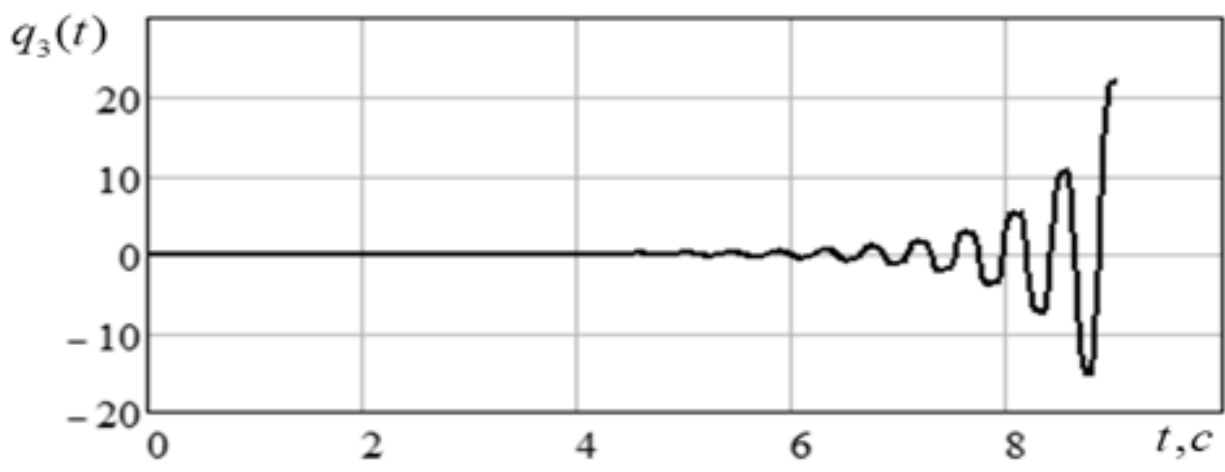

Рис. 5. Зміна третьої узагальненої координати пошкодженої конструкції

Внаслідок початкового збурення ЛА від пориву після перехідного процесу має місце швидке зростання коливань крила. Як видно з наведених вище фрорм власних коливань, крило в потоці набуває змінних деформацій згинання і кручення.

На рис. 6 показано зміну з часом переміщення кінця крила та його кута повороту. Видно, що за лічені секунди деформація сягає небезпечного рівня. Аеродинамічні сили і сили інерції в процесі коливань мають період $T=0,425$ c, вони періодично закручують крило, а це викликає додаткове надходження енергії в систему.

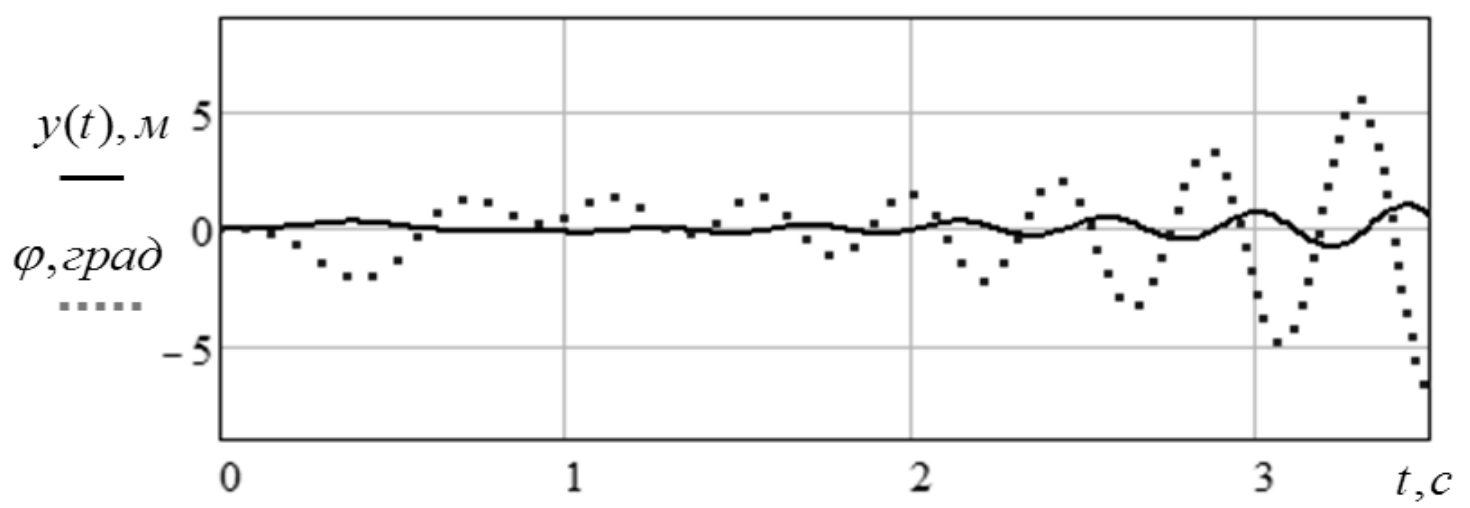

Рис. 6. Зростання з часом переміщення та кута повороту кінця крила пошкодженої конструкції

На рис. 7 показано розподіл кутів закручування перерізів крила в деякий момент часу.

Можна зробити висновок, що перша та друга узагальнені координати роблять суттєвий внесок у зростання місцевих кутів атаки крила. Аеродинамічне навантаження на переміщеннях пошкодженої конструкції здійснює за період додатну роботу, яка перевищує роботу сил демпфірування. В результаті конструкція стає нестійкою у потоці і відбувається ії швидке катастрофічне руйнування.

Таким чином, на основі достатньо простої ММ аеропружності і числового експерименту на ЕОМ проведені параметричні дослідження щодо небезпечних меж пошкоджень конструкції крила. 


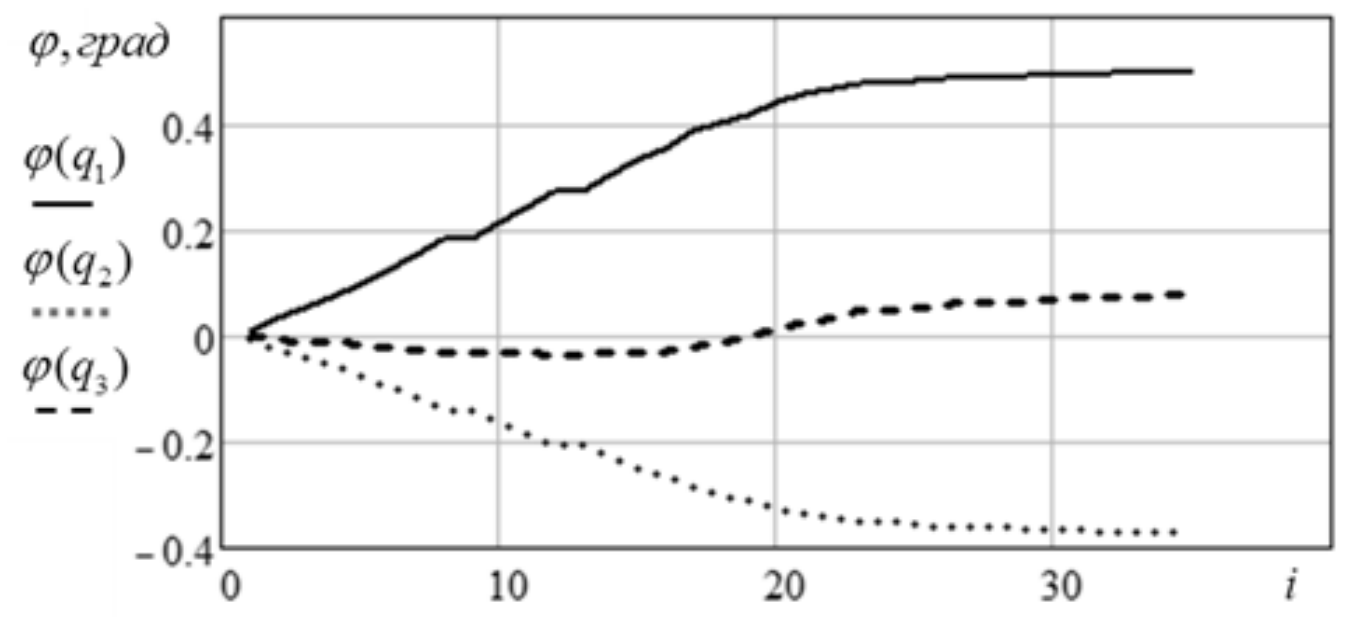

Рис. 7. Внесок узагальнених координат $q_{1} q_{2}$ та $q_{3}$ у закручування крила пошкодженої конструкції

Відзначимо, що дані розрахункові моделі можуть використовуватися на етапах проектування, експлуатації та модернізації ЛА. Слід підкреслити, що випереджаюче функціонування ММ об'єктів можливо тільки при постійному коригуванню моделі на основі даних фрізичного моделювання системи і льотного експерименту.

\section{Список літератури}

1. Кузнецов, О.А. Динамические нагрузки на самолет [Текст]/ О.А. Кузнецов. - М.: Изд-во физ.-мат. лит., 2008. - 264 с.

2. Бисплингхофрф, Р. Л. Аэроупругость [Текст] / Р. Л. Бисплингхоффф, Х. Эшли, Р. Л. Хелфмен. - М. : Изд-во иностр. лит., 1958. - 799 с.

3. Онищенко В.М. Динамична реакція і навантаження літака при дії атмосфрерної турбулентності [Текст] : навч. посіб. / В. М. Онищенко. - Харків: ХАИ, 2018. - 176 с.

\section{References}

1. Kuznetsov, O.A. Dynamicheskie nagruzki na samolet [Text]/ O.A. Kuznetsov. - M.: Izd-vo fiz.-mat. lit., 2008. - 264 p.

2. Bisplinghoff, R. L. Aerouprugostj [Text] / R. L. Bisplinghoff, H. Ashli, R. L. Helfman. - M. : Izdd-vo inostr. lit., 1958. - 799 p.

3. Onishenko V.M. Dinamicha reaktsiya I navantazhennya litaka pri dii atmosfernoi turbulentnosti [Text] : navch. posib. / V. M. Onishenko. - Kharkiv: KhAl, 2018. - 176 p.

Поступила в редакцию 20.01.2020, рассмотрена на редколлегии 22.01.2020

\section{Dynamic response and stability of transport plane damaged structure}

In the process of designing and operating the aircraft, it is important to determine the ultimate state of the structure, taking into account the dynamic load of the structure and its stability. The ultimate state of the structure is characterized by damage, in which the structure still retains the ability to withstand without 
catastrophic destruction of the maximum operating load. The main method of studying the stability of the structure is the dynamic method. It allows us to investigate the perturbed motion of a structure as a nonconservative system for some initial perturbation. The monotonic departure of the system from the equilibrium position or its oscillations with increasing amplitudes indicate the instability of the structure. The paper analyzes the effect of damage to the aircraft structure on its dynamic stability based on the determination of the dynamic response of the aircraft to some non-stationary perturbation, for example, on the action of a turbulent atmosphere. The method of computational analysis is used to study the dynamic stability of the structure. The basis of this method is mathematical modeling (MM) of the operation of the aircraft in the form of a system of equations of motion and deformation of the structure. The problem of dynamic aeroelasticity is considered the behavior of the elastic damaged structure of the aircraft in the air flow to the initial perturbation. On the basis of computer simulation, the dynamic stability of the elastic structure, its oscillating or quasi-static (aperiodic) deformation motion within the flight range of the aircraft is estimated. On the basis of parametric researches the limits of instability of a design at the set damages for typical operating conditions are estimated. The relevance of the direction focused on the creation and advanced operation of MM aircraft - their mathematical backups in the process of design and operation of aircraft due to the complexity and limited capabilities of ground experimental installations and flight experiment. It is noted that the condition for the application of this method is the formed MM operation of the aircraft and the availability of information on the mass-inertial, stiffness and aerodynamic characteristics of the aircraft.

Keywords: dynamic reaction; stability of a design; atmospheric turbulence; mathematical model; frequency and shape of natural oscillations; elasticity of a design; generalized force; generalized mass.

\section{Відомості про авторів:}

Іленко Євген Юрійович - к.Т.н., доцент, заступник начальника каф. конструкції та міцності літальних апаратів та двигунів Харківського національного університету повітряних сил імені Івана Кожедуба, Харків, Україна, i2504616117@meta.ua, ORCID 0000-0001-9405-6598.

Онищенко Володимир Михайлович - к.Т.н., доцент каф. конструкції та міцності літальних апаратів та двигунів Харківського національного університету повітряних сил імені Івана Кожедуба, Харків, Україна, vladimironisenko83@gmail.com, ORCID 0000-0002-0556-6552.

\section{About the Authors:}

Yevhen Ilenko - Ph.D., Associate Professor, Deputy Chief of Department design and strength of aircraft and engines of Ivan Kozhedub Kharkiv National University of Air Force, Kharkiv, Ukraine, i2504616117@meta.ua, ORCID 00000001-9405-6598.

Vladimir Onishchenko - Ph.D., Associate Professor design and strength of aircraft and engines of Ivan Kozhedub Kharkiv National University of Air Force, Kharkiv, Ukraine, vladimironisenk083@gmail.com, ORCID 0000-0002-0556-6552. 